\title{
Pengembangan Website "Sayang Anak Indonesia” Gabungan Gereja Baptis Indonesia
}

\author{
Monica Muryawati ${ }^{1}$, Bambang Ismanto ${ }^{2}$ \\ ${ }^{1}$ Sekolah Tinggi Teologi Baptis Indonesia, Semarang, Jawa Tengah \\ ${ }^{2}$ Magister Manajemen Pendidikan Universitas Kristen Satya Wacana, Salatiga, Jawa Tengah \\ 1942017004@student.uksw.edu, ${ }^{2}$ bambang.ismanto@uksw.edu
}

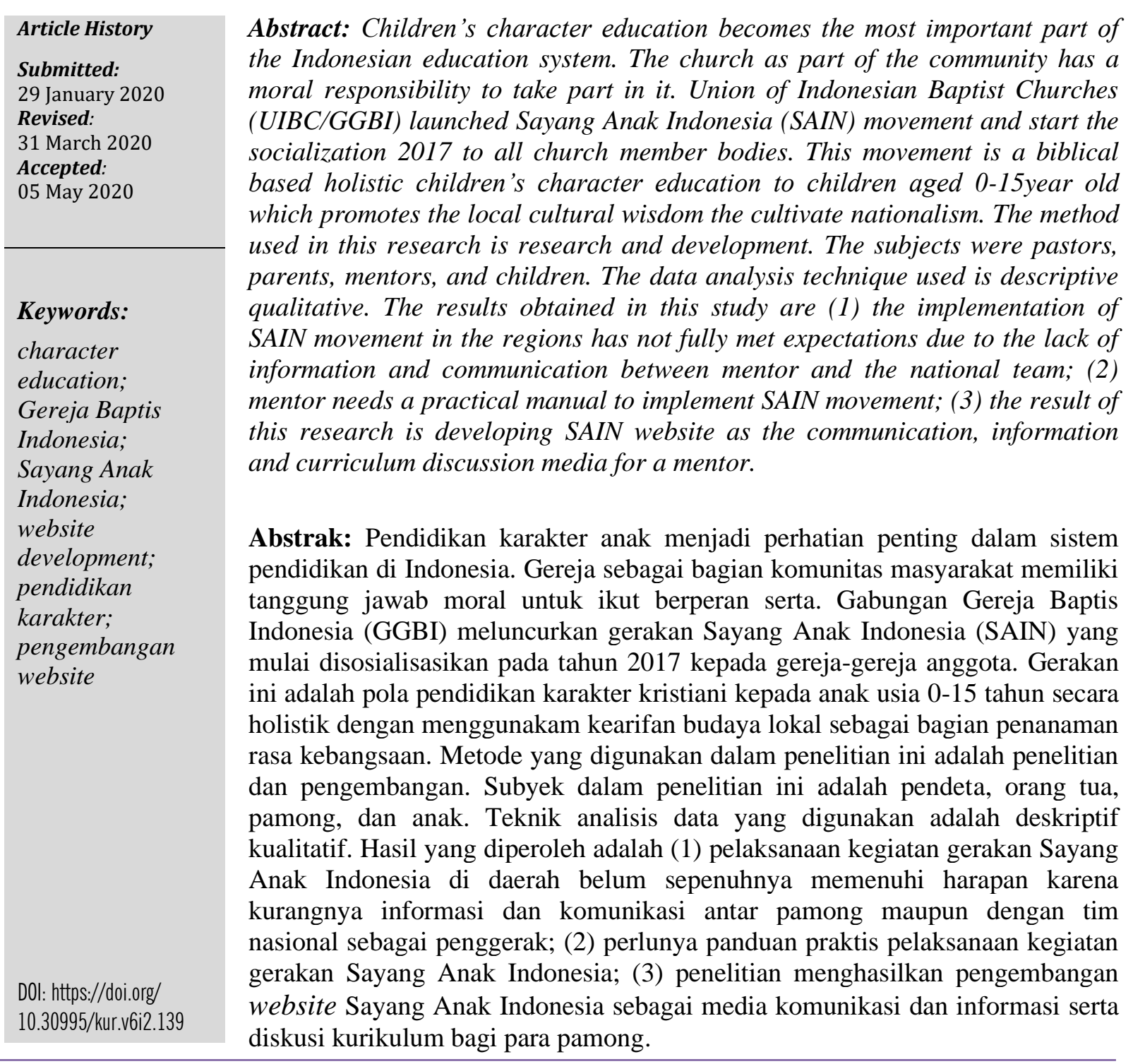

\section{Pendahuluan}

Pemerintah Indonesia cukup gencar menggulirkan gerakan nasional pembangunan karakter. Dalam percepatan implementasinya, pemerintah bergerak secara khusus dalam system pendidikan yang menanamkan nilai-nilai karakter dan kebangsaan yang unggul. Berdasarkan 
hasil survey yang dikeluarkan oleh Badan Pusat Statistik, Indeks Pembangunan Manusia mengalami peningkatan meskipun tidak begitu signifikan pertumbuhannya seperti yang tampak dalam tabel di bawah ini.

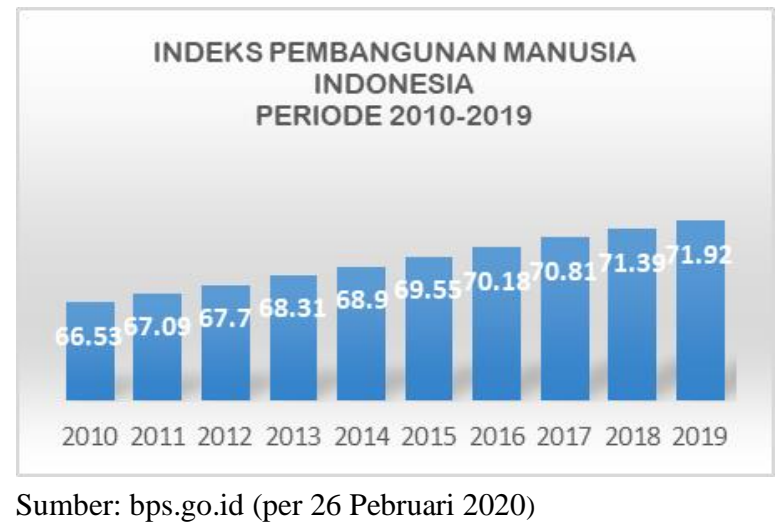

Tabel 1: Indeks Pembangunan Manusia Indonesia Periode 2010-2019

Grafik di atas menunjukkan bahwa pembangunan manusia Indonesia masih harus ditingkatkan supaya semakin memacu kemajuan bangsa Indonesia secara keseluruhan. Dalam peningkatan pembangunan manusia Indonesia, pendidikan masih menjadi idola utama untuk menghasilkan sumber daya manusia yang unggul.

Di sisi lain, institusi-institusi pendidikan masih harus berjuang keras untuk dapat melakukan pendidikan karakter yang baik dan menghasilkan peserta didik yang berkarakter unggul. Raihan Putry menuliskan, bahwa munculnya kepanikan sekolah-sekolah terhadap perilaku peserta didiknya yang semakin menunjukkan dekadensi moral. Banyak sekolah yang mengalami kegagalan dalam melakukan pendidikan karakter terhadap peserta didiknya. ${ }^{1}$ Pendidikan yang digadang-gadang menjadi ujung tombak utama dalam pembangunan manusia yang unggul, harus terus memperbaiki diri sehingga mampu menghasilkan manusia yang berkarakter. Sistem pendidikan yang mumpuni dan mengikuti perkembangan zaman menjadi bagian penting dalam percepatan pembangunan manusia terutama dalam pendidikan karakternya. Perubahan system pendidikan yang mau tidak mau harus mengikuti kemajuan pesat ilmu pengetahuan dan teknologi yang ada menjadi sebuah kebutuhan memasuki era revolusi industri keempat. Pengelolaan pendidikan juga menjadi bagian tak terpisahkan dalam lembaga pendidikan formal, nonformal, maupun informal. Pengelolaan atau manajemen pendidikan yang baik akan berdampak kepada kualitas output atau mutu pendidikan yang dihasilkan, apakah sesuai dengan tujuan pendidikan yang efektif dan efisien.

Hal tersebut juga berlaku bagi pengelolaan sistem pendidikan gereja yang perlu terus dikembangkan sesuai dengan tujuan pendidikan gereja itu sendiri. Gabungan Gereja Baptis Indonesia (GGBI) menyadari pentingnya turut berperan serta dalam upaya menghasilkan pendidikan gereja khususnya untuk anak-anak dengan lebih baik. Dalam Kongres IX tahun 2015, GGBI meletakkan dasar rencana strategis jangka panjang 2015-2040. Dalam bagian rencana strategis secara umum tersebut dibentuklah Departemen Anak. Dalam perkembangannya untuk percepatan pelayanan dan pendidikan karakter secara holistik sesuai nilai-nilai

${ }^{1}$ Raihan Putry, "Nilai Pendidikan Karakter Anak Di Sekolah Perspektif Kemendiknas," Gender Equality: Internasional Journal of Child and Gender Studies 4, no. 1 (2018): 39-54. 
kristiani, muncullah gerakan Sayang Anak INdonesia (SAIN). Gerakan ini bertujuan agar Gereja Baptis Indonesia kembali memuridkan, mendidik dan mengembangkan anak-anak menjadi pribadi yang semakin seperti Kristus sehingga mereka menjadi generasi yang berdampak bagi gereja, masyarakat, bangsa, bahkan dunia seperti yang tertulis dalam Anggaran Dasar dan Anggaran Rumah Tangga Gabungan Gereja Baptis Indonesia pasal 8 ayat 3, "Menyelenggarakan pendidikan sebagai sarana peningkatan kecerdasan, kesadaran, dan tanggung jawab serta kemampuan untuk berperan dan mengambil bagian dalam pembangunan Indonesia."2

Gerakan SAIN ini mengkhususkan diri untuk memuridkan anak mulai dari usia 0-15 tahun. Rentang usia ini diambil, karena pada masa inilah masa yang paling baik untuk membentuk karakter anak dan mempersiapkan mereka memasuki masa usia produktif yang panjang serta penuh tantangan. Hal ini sejalan dengan pendapat Helmawati yang menyimpulkan bahwa usaha dalam rangka mengembangkan potensi serta membentuk akhlak, watak, dan kepribadian adalah pendidkan karakter. ${ }^{3}$ Sebagai sebuah gerakan nasional konsep yang dianggap baru, memunculkan banyak pertanyaan dan kekuatiran akan keberhasilan program ini. Maka peneliti mengadakan penelitian pengembangan yang berfokus pada manajemen pengelolaan gerakan pemuridan SAIN yang sesuai bagi Gabungan Gereja Baptis Indonesia dan dapat diakses dengan mudah oleh setiap pamong yang ada.

Penelitian ini berusaha untuk menjawab pertanyaan bagaimana dapat mengembangkan sebuah media yang menjadi sarana informasi dan komunikasi mengenai panduan pelaksanaan pemuridan SAIN GGBI yang lebih efektif dan efisien untuk para pamong anak di gerejagereja Baptis di seluruh Indonesia. Selain itu penelitian ini bertujuan untuk mengembangkan media yang dapat diakses oleh semua pihak yang berkepentingan dalam kegiatan pemuridan SAIN GGBI dalam mempersiapkan, melaksanakan serta mengevaluasi kegiatan pemuridan SAIN GGBI. Desain produk yang akan dikembangkan dalam penelitian pengembangan ini adalah: (1) Situs web SAIN GGBI; (2) Materi dalam situs web ini mengacu kepada buku utama panduan SAIN GGBI. Fokus dari desain situs web ini adalah untuk memudahkan pamong dalam pelaksanaan kegiatan pemuridan SAIN sehingga dapat melayani anak-anak dengan lebih baik dan lebih baik; (3) Kriteria dalam pengembangan desain situs web ini adalah Kebenaran yang tidak bertentangan dengan Rencana Strategis Gerakan SAIN dan ajaran agama Kristen yang menjadi dasar bagi Gereja Baptis Indonesia, Keterlaksanaan, yaitu bahwa situs web ini dapat diakses dan dijalankan dengan mudah oleh pamong dan orang tua di Gereja Baptis Indonesia, dan Kejelasan, yaitu bahwa materi yang terdapat dalam situs web ini dapat dipahami dengan mudah serta tidak menimbulkan multi tafsir yang dapat membingungkan pamong dan orang tua; (4) Desain situs web ini rencananya akan memuat: (1) Profil yang berisi sekilas tentang SAIN, Landasan dan Tim SAIN; (2) Kegiatan SAIN; (3) Forum Diskusi; dan (4) Kontak Pribadi.

\footnotetext{
${ }^{2}$ Gabungan Gereja Baptis Indonesia, Minit Kongres X Gabungan Gereja Baptis Indonesia, issued 2015, 438.

${ }^{3}$ Helmawati, Pendidikan Keluarga: Teoritis Dan Praktis. (Bandung: Remaja Rosdakarya, 2014), 156.
} 


\section{Metode Penelitian}

Penelitian ini adalah penelitian dan pengembangan. Sugiyono menuliskan, penelitian pengembangan merupakan metode penelitian yang digunakan untuk meneliti dalam upaya mengembangkan produk yang telah ada (inovasi) maupun untuk menciptakan produk baru (kreasi) yang teruji. ${ }^{4}$ Secara khusus penelitian ini mengacu kepada pengembangan pendidikan. Menurut Borg and Gall, penelitian pengembangan pendidikan atau educational research and development didefinisikan sebagai sebuah tahapan yang dipakai untuk mengembangkan serta memberikan validasi produk pendidikan. ${ }^{5}$ Dalam penelitian ini, peneliti ingin mengembangkan produk panduan teknis pelaksanaan kegiatan pemuridan anak SAIN di Gereja Baptis Indonesia. Pendekatan yang dilakukan dalam mengumpulkan data menggunakan pendekatan kualitatif.

Tahapan penelitian dan pengembangan yang dilakukan oleh peneliti menjadi proses seperti gambar di bawah ini:

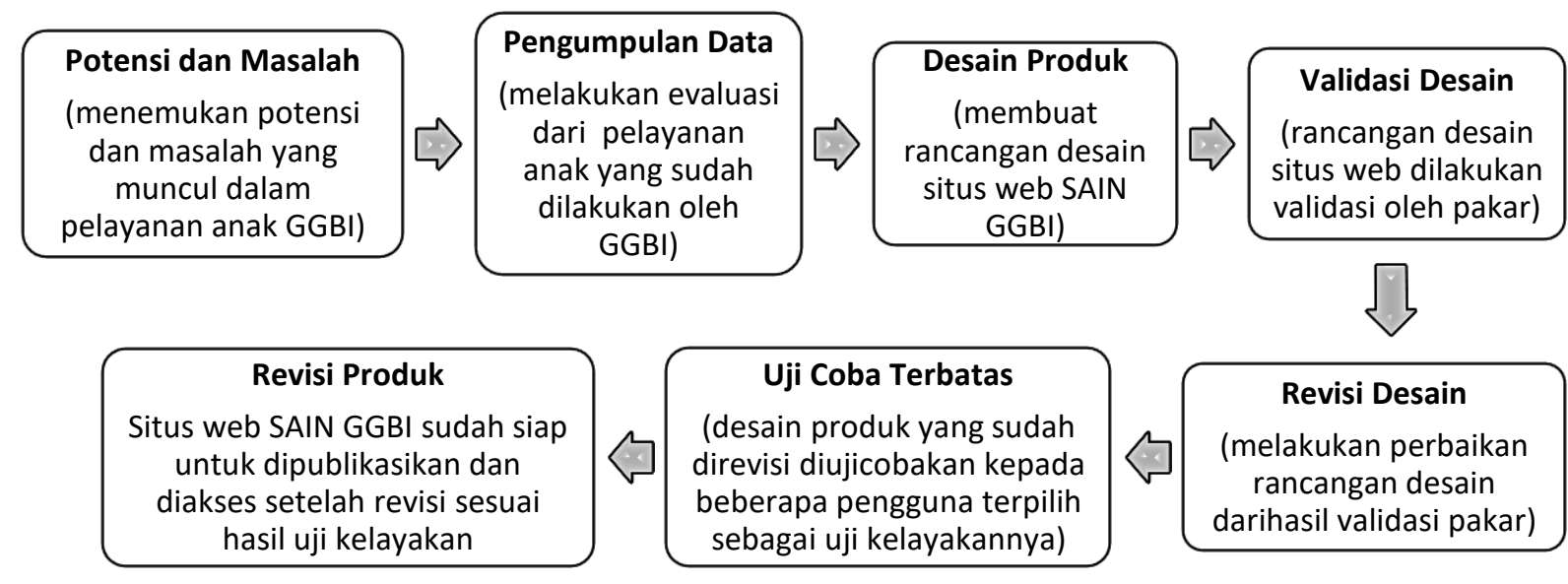

Gambar 1: Langkah-langkah penelitian R \& D (adaptasi dari Borg and Gall)

\section{Deskripsi}

\section{Gerakan Sayang Anak INdonesia dan Pendidikan Karakter}

Kamus Besar Bahasa Indonesia mendefinisikan gerakan sebagai perbuatan atau keadaan bergerak (air, laut, mesin); pergerakan, usaha, atau kegiatan dalam lapangan sosial (politik dan sebagainya): tindakan terencana yang dilakukan oleh suatu kelompok masyarakat disertai program terencana dan ditujukan pada suatu perubahan atau sebagai gerakan perlawanan untuk melestarikan pola-pola dan lembaga-lembaga masyarakat yang ada ${ }^{6}$; Gabungan Gereja Baptis Indonesia memilih kata gerakan dengan alasan bahwa kegiatan bukanlah suatu organisasi baru namun menjadi milik dari semua organisasi dalam gereja dan GGBI demi tercapainya perubahan yang signifikan dalam memuridkan anak-anak.

\footnotetext{
${ }^{4}$ Sugiyono, Metode Penelitian Dan Pengembangan: Research and Development (Bandung: Alfabeta, 2015), 395.

${ }^{5}$ Walter R. Borg and Meredith Damien Gall, Educational Research: An Introduction Third Edition (New York: Longman, Inc, 1978), 624.

${ }^{6}$ Kamus Besar Bahasa Indonesia, 5th ed. (Badan Pengembangan Bahasa dan Perbukuan, Kementerian Pendidikan dan Kebudayaan Republik Indonesia, 2019).
} 
Jan S. Aritonang menuliskan mengenai sejarah perkembangan GGBI yang secara sadar menggunakan Bahasa Indonesia dan melayani warga yang multi etnis. ${ }^{7}$ Sampai saat ini, GGBI masih tetap konsisten sebagai gereja yang injili dan merangkul semua kelompok masyarakat Indonesia yang multikultural. Pemuridan menjadi bagian penting bagi GGBI. Pemuridan dalam gerakan SAIN GGBI menggunakan istilah pamong untuk pendidik karena lebih mengarah kepada kearifan budaya lokal, yang dalam Kamus Besar Bahasa Indonesia berarti pengasuh; pendidik (guru); pengurus. SAIN merupakan singkatan dari Sayang Anak Indonesia, dipilih sebagai nama gerakan nasional ini karena GGBI mau menjadi mitra Allah dalam memuridkan anak-anak Indonesia usia 0-15 tahun sebagai pengikut Kristus yang unggul dan berdampak baik bagi gereja, bangsa dan dunia. ${ }^{8}$ Dengan semboyannya "Mengasihi Anak, Membangun Bangsa", gerakan SAIN GGBI ini mau berperan serta dalam membangun generasi emas yang menjadi tujuan pendidikan nasional melalui pendidikan agama Kristen yang berbasis budaya bangsa.

SAIN GGBI mengambil bagian peran serta dalam pendidikan nasional di bidang pembentukan karakter. Pemuridan SAIN GGIB lebih berfokus kepada anak-anak karena seperti yang dituliskan oleh Candra Agung Pambudi bahwa Allah memandang anak istimewa, maka sudah sepatutnya gereja melayani anak-anak dengan cara istimewa. ${ }^{9}$ Sementara itu Royo Haryono menuliskan tiga dasar eklesiologi dalam melakukan pemuridan anak ini, yaitu: 1) setiap Gereja Baptis Indonesia adalah penerima mandat Agung Tuhan Yesus untuk "membuat murid" (termasuk anak-anak) menjadi penggenapan rencana Allah menyelamatkan dunia dari dosa dan menumbuhkannya menjadi murid yang hidup dan bertumbuh dengan karakter Yesus. 2) komitmen Gereja Baptis Indonesia terhadap panggilan penjangkauan dan pengembangan anak. 3) ketetapan organisasi GGBI menjawab tantangan pemuridan anak di era sekarang yang dibangun atas kesadaran panggilan untuk menyelamatkan generasi dari berbagai ancaman persoalan krusial penyebab dan penghancur masa depan anak. ${ }^{10}$ Noto Sumarto mengemukakan dalam kerangka nasionalisme, kearifan lokal menjadi jembatan praktis menyampaikan pesan-pesan moral atau rohani yang telah lama dipahami dan kekristenan mengisinya dengan nilai-nilai kebenaran, pemuridan, pengembangan akhlak dan budaya, serta pengejawantahan dari nilai-nilai keselamatan. ${ }^{11}$

Doni Wijaya menekankan pentingnya keteladanan pamong dalam pemuridan SAIN GGBI demikian juga pengenalan akan anak didik serta nilai social yang berlaku di masyarakat lokal dan diisi dengan nilai-nilai kekristenan agar adaptasi pengajaran dan pembinaan dapat sesuai dengan ajaran Alkitab dan nilai budaya setempat. ${ }^{12}$ Monica Muryawati menuliskan bahwa pemuridan anak dengan konsep bermain dipilih karena ekspresi anak terhadap

\footnotetext{
${ }^{7}$ Jan S Aritonang, Berbagai Aliran Di Dalam Dan Di Sekitar Gereja: Edisi Revisi (Jakarta: BPK Gunung Mulia, 2016), 168.

${ }^{8}$ Monica Muryawati et al., Layang-Layang \& Rujak: Melayang Tinggi Dalam Beragam Rasa Dan Warna Bagi Anak Indonesia-Bunga Rampai Buku Panduan SAIN GGBI, ed. Monica Muryawati (Jakarta: Gabungan Gereja Baptis Indonesia, 2018), 8.

${ }^{9}$ Muryawati et al., Layang-Layang \& Rujak: Melayang Tinggi Dalam Beragam Rasa Dan Warna Bagi Anak Indonesia-Bunga Rampai Buku Panduan SAIN GGBI.

${ }^{10}$ Muryawati et al.

${ }^{11}$ Muryawati et al.

${ }^{12}$ Muryawati et al.
} 
dunia yang ada disekitarnya adalah melalui permainan. Permainan merupakan simulasi akan kehidupan nyata yang sedang dan akan meraka hadapi. ${ }^{13}$ SAIN GGBI ini berfokus pada pembentukan karakter anak Indonesia sesuai ajaran Kristiani melalui permainan yang berbasis kearifan local. Hal ini sesuai dengan apa yang seharusnya menjadi peran serta pendidik anak, secara khusus PAUD, menurut Ika Budi Maryatun adalah menguasai strategi pengembangan anak usia dini agar dapat merencanakan pembelajaran yang sesuai dengan tujuan pengembangannya. Hal penting lainnya adalah, pendidik perlu memahami karakteristik anak sesuai usia, budaya, dan lingkungannya sehingga apa yang diajarkan mudah dipahami anak dan dapat dilakukan dengan mudah seperti sifat alamiah sebagai pengamat dan peniru. ${ }^{14}$

Menyimak definisi pendidikan dari sisi hukum berdasarkan Undang-Undang RI Nomor 20 Tahun 2003 tentang Sisdiknas, pasal 1 ayat (1), yaitu "Pendidikan adalah usaha sadar dan terencana untuk mewujudkan suasana belajar dan proses pembelajaran agar peserta didik secara aktif mengembangkan potensi dirinya untuk memiliki kekuatan spiritual keagamaan, pengendalian diri, kepribadian, kecerdasan akhlak mulia serta ketrampilan yang diperlukan dirinya, masyarakat, bangsa dan negara." Membahas mengenai peserta didik dalam pasal 1 ayat (4) menuliskan "Peserta didik ialah anggota masyarakat yang berusaha mengembangkan potensi diri melalui proses pembelajaran yang tersedia pada jalur, jenjang, dan jenis pendidikan."15 GGBI memandang penting pendidikan, khususnya di bidang pembentukan karakter yang memiliki kekuatan spiritual keagamaan sehingga pemuridan SAIN GGBI menjadi salah satu bentuk pendidikan karakter unggulan yang dimiliki oleh GGBI. Segala bentuk pendidikan atau lembaga pendidikan baik formal, non formal, informal ataupun berbasis masyarakat didirikan untuk dapat menghasilkan generasi yang berkualitas sesuai standar mutu yang ditetapkan oleh lembaga tersebut. GGBI menetapkan kualitas mutu generasi yang dihasilkan sebagai generasi yang memiliki karakter Kristus yang berdampak bagi gereja, bangsa dan dunia.

Suryana dan Rusdiana menuliskan bahwa Indonesia merupakan negara yang memiliki kekayaan khazanah budaya karena suku bangsa, etnis, kelompok social, kepercayaan, agama serta kebudayaan yang sanat beragam dari masing-masing daerah Hal tersebut dapat memunculkan konflik dan perpecahan karena beragamnya keinginan yang disebabkan oleh latar belakang, cara pandang yang berbeda sehingga diperlukan paham pluralism dan multikulturalisme untuk dapat mempersatukan bangsa Indonesia. ${ }^{16}$ Diperlukannya paradigma pendidikan multikultural untuk menghadapi pluralism budaya sehingga anak didik memiliki sikap apresiatif terhadap keragaman perbedaan dan dapat meredam potensi kerusuhan dan konflik. ${ }^{17}$ Pentingnya pendidikan multicultural dimulai dari anak-anak yang ditangkap dan dijadikan bagian kekhasan dalam pemuridan SAIN GGBI dengan konsep permainan berbasis kearifan

\footnotetext{
${ }^{13}$ Muryawati et al.

${ }^{14}$ Ika Budi Maryatun, "PERAN PENDIDIK PAUD DALAM MEMBANGUN KARAKTER ANAK," Jurnal Pendidikan Anak 5, no. 1 (2016): 747-52.

${ }^{15}$ Indonesia Patent, Undang-Undang RI Nomor 20 tentang Sistem Pendidikan Nasional, issued 2003.

${ }^{16}$ Yaya Suryana and H.A. Rusdiana, Pendidikan Multikultural: Suatu Upaya Penguatan Jati Diri Bangsa Konsep-Prinsip-Implementasi (Bandung: Pustaka Setia, 2015), 93.

${ }^{17}$ Suryana and Rusdiana, Pendidikan Multikultural: Suatu Upaya Penguatan Jati Diri Bangsa - KonsepPrinsip-Implementasi.
} 
budaya local. Konsep tersebut menjadi bagian pengenalan Indonesia yang beragam tetapi dapat dipersatukan dengan lebih menghargai keberagaman yang dimiliki.

Gereja harus melepaskan diri dari konsep sekadar memberikan reward and punishment dalam pengajarannya, tetapi lebih berfokus kepada bagaimana menjalani kehidupan pribadi dan bermasyarakat sesuai dengan kaidah ajaran Kristen. Hora dalam penelitiannya terhadap sekolah-sekolah Kristen di Inggris menunjukkan hubungan berdasarkan program seperti pemuridan satu-satu dan pengembangan pendampingan professional perlu dipertimbangkan oleh sekolah untuk menanamkan kedewasaan rohani remaja. ${ }^{18}$ Maka peran penting gereja sangat diperlukan.

Daniel Nuhamara berpendapat bahwa dalam implementasi pendidikan karakter, pendidikan agama memiliki kekhususan secara lebih luas dalam penanamannya dibandingkan mata pelajaran atau mata kuliah yang lain dan masih ada banyak hal lain yang akan terus dikembangkan. Peran keluarga dan komunitas agama masih sangat kuat dan penting dalam penanaman nilai-nilai moral serta kebajikan bagi masyarakat Indonesia. Kedua lembaga tersebut merupakan agen penting pendidikan karakter. ${ }^{19}$ Sementara itu, Helmawati mendefinisikan pendidikan karakter sebagai usaha membantu mengembangkan potensi manusia agar terbentuk akhlak, watak, dan kepribadian sebagai manusia. ${ }^{20}$ Lebih lanjut Helmawati menyebutkan bahwa kata-kata atau perintah saja tidak cukup dalam membentuk anak berkarakter. Karena anak adalah imitator ulung, maka peran pendidik atau orang tua menjadi titik sentral. Menurut Helmawati metode yang umum dan telah teruji dapat membentuk anak berkarakter diantaranya adalah peneledanan, percontohan, pembiasaan, pengulangan, metode pelatihan, dan metode motivasi. ${ }^{21}$ Dalam proses pendidikan karakter, pembiasaan dan keteladanan menjadi bagian utama agar anak dapat lebih memahami serta bisa mempraktikkannya dalam kehidupan yang dijalaninya.

\section{Teknologi Informasi Sebagai Pengembangan Kegiatan Pedidikan}

Keberadaan teknologi informasi dan internet merupakan penunjang pembelajaran yang cukup efektif dan praktis bagi para pendidik, dalam konteks penelitian ini adalah pamong dan orang tua anak. Kurikulum pendidikan menurut presiden direktur Telkom Telstra, Erik Meijer, sangat penting dan perlu melakukan penyesuaian yang sesuai dengan perkembangan zaman karena perubahan yang begitu cepat memasuki era revolusi industry yang keempat. Lebih lanjut Erik mengingatkan pula, bahwa tetap adanya resiko dampak negative dari revolusi industri 4.0 yang identik dengan teknologi di sisi etika dan moral. Penanaman nilai-nilai etika dan moral oleh institusi pendidikan sangat penting untuk dapat melahirkan inovasi-inovasi yang tidak meninggalkan sisi kemanusiaan karena tergerus oleh teknologi. ${ }^{22}$

Otomatisasi serta konektivitas internet dengan perangkat serta teknologi penyerta merupakan ciri dari era revolusi industri keempat. Manusia dituntut untuk lebih cerdas bersikap

\footnotetext{
${ }^{18}$ Anne Puidk Hora, "Fostering Spiritual Formation of Millennials in Christian Schools," Journal of Research on Christian Education 26, no. 1 (2017): 56-77, https://doi.org/• 10.1080/10656219.2017.1282901.

${ }^{19}$ Daniel Nuhamara, "Pengutamaan Dimensi Karakter Dalam Pendidikan Agama Kristen," JURNAL JAFFRAY 16, no. 1 (2018): 93-114, https://doi.org/10.25278/jj71.v16i1.278.

${ }^{20}$ Helmawati, Pendidikan Keluarga: Teoritis Dan Praktis.

${ }^{21}$ Helmawati.

${ }^{22}$ Jabar Ekspress, "Pendidikan-Karakter-Hadapi-Era-Industri-4-0,” Jabar Ekspress. Com, 2018.
} 
terhadap keadaan di era ini. Tantangan dan peluang yang ditawarkan oleh era revolusi industri keempat ini kepada seluruh lapisan masyarakat, tidak terkecuali kepada dunia pendidikan. Era revolusi industri keempat ini memberikan kemudahan dengan berbagai fasilitas, namun membuat kita tidak bisa bermanja dan terlena karena kurangnya pengawasan serta pengendalian akan membawa generasi muda menjadi generasi yang konsumtif dan memiliki ketergantungan. ${ }^{23} \mathrm{Hal}$ ini sesuai dengan yang ditemukan oleh Marcelino Sumolang dalam penelitiannya di desa Tounelet Kecamatan Langowan Barat, yang menyimpulkan bahwa perlunya pemahaman dan pendampingan kepada generasi muda sehingga mereka bisa selektif dalam mengakses situs-situs internet serta memanfaatkannya secara maksimal dan bermanfaat bagi mereka. ${ }^{24}$

Berdasarkan hasil survei Badan Pusat Statistik, peningkatan signifikan terjadi pada kelompok usia muda dalam penggunaan internet dan telepon genggam, seperti yang tergambar dalam beberapa tabel di bawah ini.

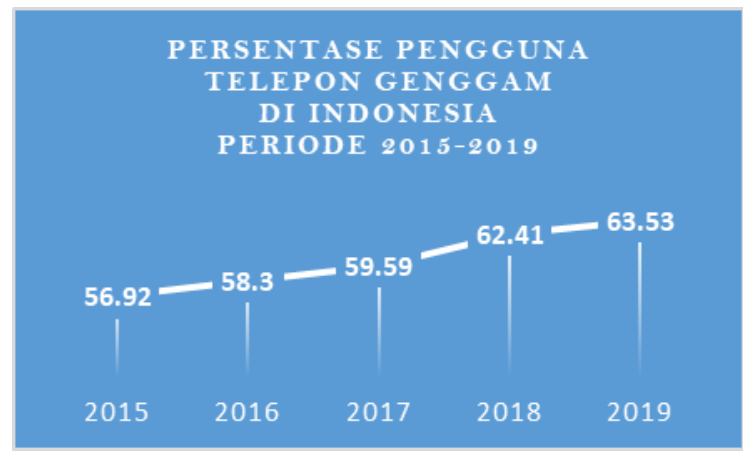

Sumber: bps.go.id (per 21 Maret 2020)

Tabel 2: Persentase Pengguna Telepon Genggam di Indonesia periode 2015-2019

Tabel diatas menunjukkan bahwa secara keseluruhan terjadi peningkatan penggunaan telepon genggam dalam masyarakat Indonesia.

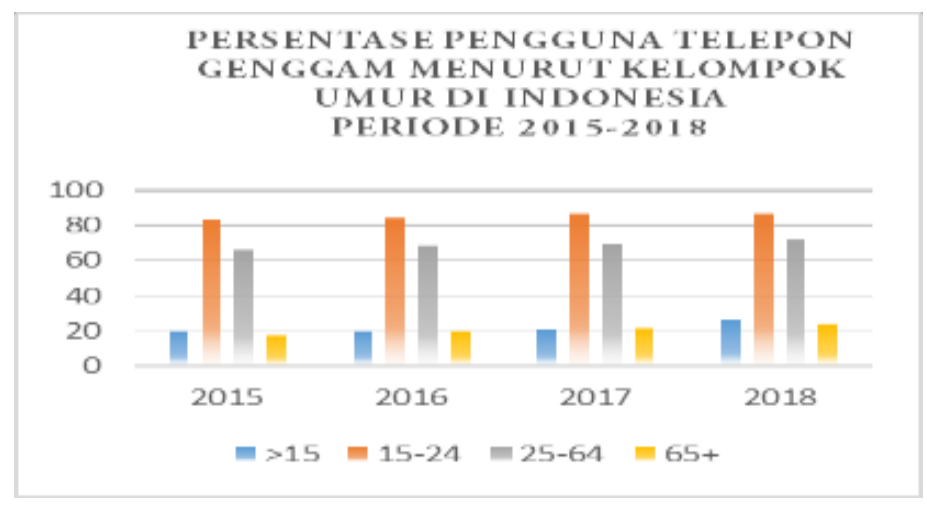

Sumber: diadaptasi dari bps.go.id (07 Oktober 2019)

Tabel 3: Persentase Pengguna Telepon Genggam Menurut Kelompok Umur (2015-2018)

\footnotetext{
${ }^{23}$ Endang Sadbudhy Rahayu, "Implementasi-Pendidikan-Karakter-Era-Revolusi-Industri-40-Ala-SmkNegeri-3-Bandung," Psmk.Kemdikbud.Go.Id, 2019, http://psmk.kemdikbud.go.id/konten/4297/implementasikarakter-era-revolusi-industri-40-ala-smk-negeri-3-bandung.

${ }^{24}$ Marcelino Sumolang, "Peranan Internet Terhadap Generasi Muda Di Desa Tounelet Kecamatan Langowan Barat,” Journal II, no. 4 (2013).
} 
Sementara tabel diatas menunjukkan terjadinya peningkatan penggunaan telepon genggam pada kelompok usia anak dan remaja di Indoneisa. Hal ini sangat penting untuk diwaspadai dan disikapi bersama.

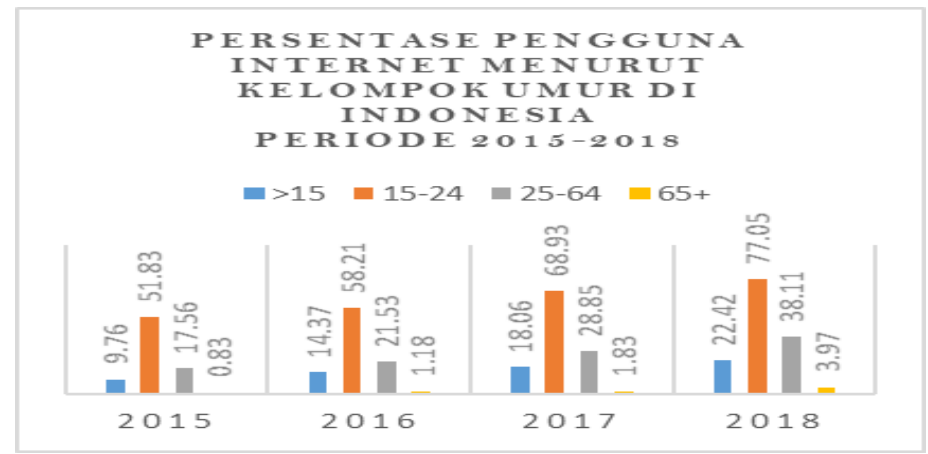

Sumber: bps.go.id (07 Oktober 2019)

Tabel 4: Persentase Pengguna Internet Menurut Kelompok Umur (2015-2018)

Tabel di atas menunjukkan tingkat penggunaan internet di kelompok usia anak dan remaja yang cukup tinggi dan mengalami peningkatan. Penggunaan internet ini sangat memerlukan adanya pendampingan dan pengawasan agar anak dan remaja tidak dapat memanfaatkannya secara postif bersama pendidik serta orang tua. Hal ini sejalan dengan penyataan Satria MA Koni yang menyebutkan perlunya pembatasan penggunaan teknologi komunikasi dan jejaring social di Indonesia untuk mengurangi dampak negatif yang merugikan diri sendiri, masyarakat, maupun bangsa dan negara. Pentingnya peran pemerintah dalam pendampingan dan edukasi cara pemanfaatannya sebagai otoritas yang memiliki kewenangan pembatasan. Di samping itu peran serta orang tua dan lingkungan sekitar sangat penting dalam melakukan pendampingan dan pengawasan bagi generasi muda. ${ }^{25}$

Sementara Suwarti menyatakan bahwa perkembangan teknologi saat ini berimbas pada penggunaan media pembelajaran melalui internet. Munculnya akses internet kecepatan tinggi yang diiringi dengan semakin tumbuh suburnya popularitas ponsel pintar di kalangan pemuda berpotensi memicu revolusi cara belajar. ${ }^{26}$ Hasil penelitian Suwarti menyebutkan bahwa peranan guru masih sangat penting dan belum dapat tergantikan oleh mesin. Hasil penelitian ini juga menyebutkan bahwa guru mengalami banyak kendala dalam mengoperasikan atau memanfaatkan internet. Harapan yang dimunculkan dalam penelitian ini menyebutkan bahwa penggunaan internet dapat memicu kreativitas guru dalam memberi tugas kepada peserta didiknya. Di sisi lain, Hamka mengingatkan bahwa pembelajaran dengan menggunakan internet merupakan sebuah sistem yang membutuhkan keterlibatan banyak faktor dan tidak bisa dilakukan secara terpisah-pisah, karena sistem tidak akan bisa berjalan dengan baik jika ada salah satu faktor saja yang terabaikan. Faktor pembiayaan dalam mengakses internet juga

${ }^{25}$ Satria MA Koni, “'Pengaruh Jejaring Sosial Terhadap Pendidikan Karakter Peserta Didik' (Studi Kasus Di SMKN 1 Bone Raya Kab. Bone Bolango Provinsi Gorontalo)," TADBIR : Jurnal Manajemen Pendidikan Islam 4, no. 2 (2016): 37-43.

${ }^{26}$ Suwarti, Bambang Sumardjoko, and Sabar Narimo, "Pemanfaatan Internet Sebagai Media Pembelajaran Di SD Negeri 1 Sindurejo Kecamatan Toroh Kabupaten Grobogan," Universitas Muhammadiyah Surakarta (2016). 
menjadi kendala tersendiri. ${ }^{27}$ Dari kedua pendapat tersebut diatas, pentingnya pengawasan serta pengendalian terhadap penggunaan internet serta saling terhubungnya semua faktor demi kelancaran sebuah sistem untuk diselenggarakan. Kreativtas dan efektifitas dalam pembelajaran menjadi salah satu keunggulan pemanfaatan perkembangan teknologi informasi yang ditawarkan untuk menjadi bagian solusi atas masalah pendidikan di Indonesia.

Dua hal penting yang dapat disimpulkan dari beberapa hasil penelitian yang dituliskan, pertama adalah penggunaan internet serta teknologi informasi dalam dunia pendidikan merupakan imbas dari perkembangan teknologi serta sudah cukup tepat untuk dilakukan demi mempermudah akses guru mendapatkan sumber belajar dan meningkatkan kreatifitasnya. Bagian kedua adalah perlunya control dalam penggunaan media teknologi informasi serta internet demi peningkatan manfaat positif internet untuk pendidikan secaa menyeluruh.

Dari diskusi yang diambil dari beberapa penelitian tersebut diatas, pengembangan jaringan website untuk SAIN GGBI merupakan salah satu cara untuk mempermudah akses bagi pamong dan orang tua untuk mendapatkan sumber belajar dan kreatifitas dalam mengadakan kegiatan SAIN di tempat mereka masing-masing. Dengan memberikan akses bagi para pamong dan orang tua, juga menjadi bagian edukasi untuk menolong mereka meningkatkan manfaat positif internet bagi pendidikan karakter anak melalui kegiatan SAIN. Pemanfaatan internet sebagai media informasi dan komunikasi bagi para pamong SAIN, juga sekaligus menolong efektifitas komunikasi untuk saling berbagi dalam membimbing anak-anak di era digital dalam menggunakan teknologi informasi secara positif.

Panduan pelaksanaan daring SAIN GGBI yang disusun oleh peneliti bertujuan untuk lebih berfokus kepada forum informasi dan komunikasi para pelaku pemuridan melalui permainan yang berbasis kearifan local dalam rangka pembentukan karakter anak sesuai karakter Kristiani. Melalui panduan daring SAIN GGBI, diharapkan para pamong lebih mudah mendapatkan akses dan ide kegiatan yang bisa diterapkan di kelompok masing-masing serta dapat dievaluasi dengan lebih baik lagi.

\section{Hasil dan Pembahasan}

\section{Hasil Penelitian}

Sampai saat ini, GGBI mengalami kesulitan untuk mendata jumlah anak yang berhasil dimuridkan selama ini. Data yang baru berhasil diperoleh yaitu melalui pendistribusian buku Sekolah Minggu oleh Lembaga Literatur Baptis yang dibeli oleh gereja-gereja anggota GGBI.

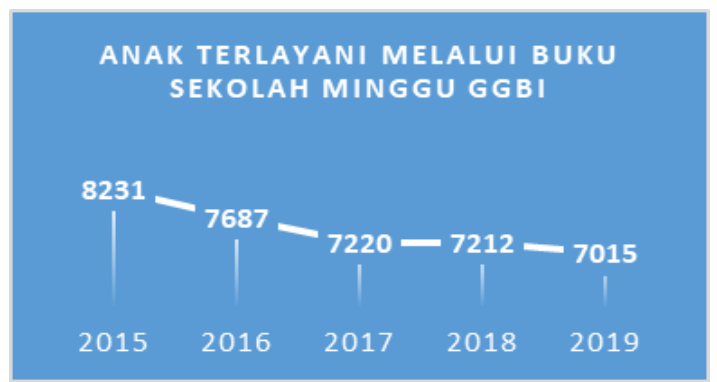

Tabel 5: Jumlah Anak Usia 0-15 tahun yang terlayani melalui buku SM GGBI

\footnotetext{
${ }^{27}$ Hamka, "Penggunaan Internet Sebagai Media Pembelajaran Pada Mahasiswa IAIN Palu," Hunafa: Jurnal Studai Islamika 12, no. 1 (2015): 95-119.
} 
Tabel di atas, sesungguhnya belum mewakili jumlah anak yang berhasil dijangkau untuk dimuridkan dan dididik oleh gereja karena masih banyak gereja-gereja local yang belum menggunakan buku Sekolah Minggu GGBI dikarenakan berbagai keterbatasan yang dimiliki. Trend yang bisa dilihat dalam tabel diatas adalah adanya penurunan jumlah buku murid SM yang didistribusikan ke gereja-gereja Baptis Indonesia.

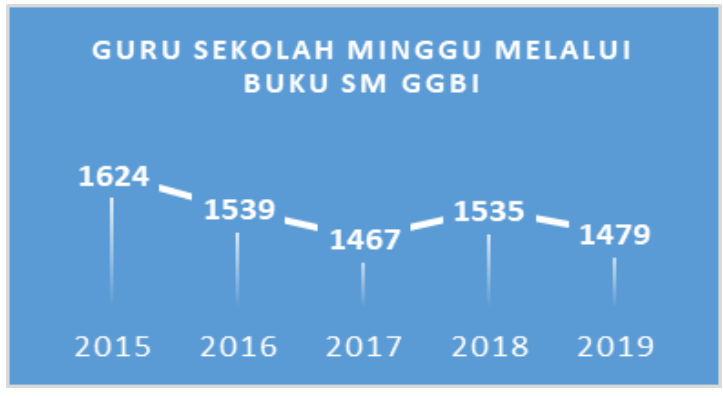

Sumber: LLB

Tabel 6: Jumlah Guru SM Usia 0-15 tahun yang melayani melalui buku SM GGBI

Tabel di atas menunjukkan jumlah guru yang melayani dalam Sekolah Minggu GGBI. Jumlah guru yang tampak dalam data, belum semuanya secara aktif dan berkesinambungan melayani anak secara intensif. Hasil pengamatan di lapangan, beberapa gereja menggunakan cara mengajar secara bergantian Hal ini membuat tidak semua guru bisa berinteraksi secara intensif untuk dapat menolong anak mengimplementasikan pelajaran Alkitab yang diperoleh di kelas Sekolah Minggu (SM) ke dalam kehidupan sehari-hari. Sama halnya dengan jumlah murid SM, jumlah guru SM melalui pendistribusian buku juga mengalami penurunan.

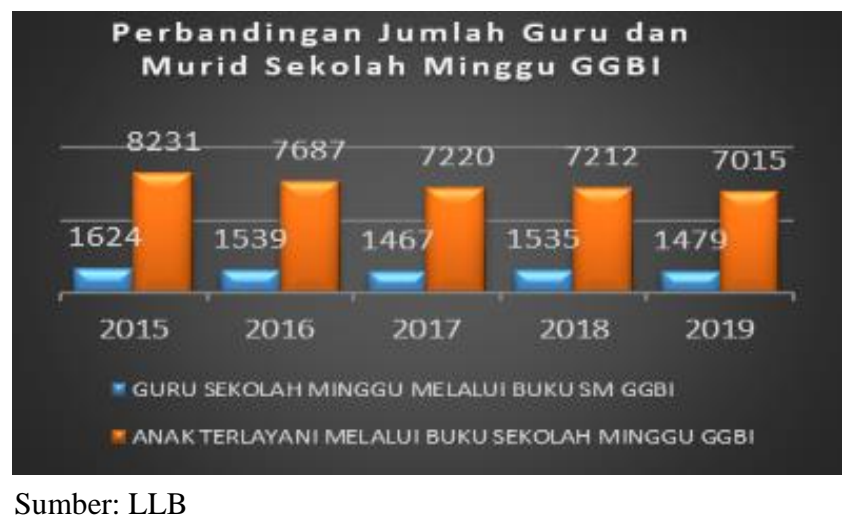

Tabel 7: Perbandingan Jumlah Guru dan Murid Usia 0-15 tahun yang terlayani melalui buku SM GGBI

Tabel di atas menunjukkan perbandingan jumlah guru yang melayani dalam Sekolah Minggu GGBI dengan jumlah murid SM yang dilayani. Dari tabel diatas, perbandingan jumlah guru dan murid konsisten di angka 1:5. Namun demikian, trend yang bisa dilihat dalam tabel diatas juga menunjukkan adanya penurunan jumlah baik murid maupun guru. Selain itu, jumlah guru yang tampak dalam data, belum semuanya secara aktif dan berkesinambungan melayani anak secara intensif. Hasil pengamatan di lapangan, beberapa gereja menggunakan cara mengajar secara bergantian Hal ini membuat tidak semua guru bisa berinteraksi secara intensif untuk dapat menolong anak mengimplementasikan pelajaran Alkitab yang diperoleh di kelas Sekolah Minggu ke dalam kehidupan sehari-hari. 
Kurang maksimalnya peran guru Sekolah Minggu dalam mendampingi anak-anak secara konsisten dan berkesinambungan juga menjadi salah satu bagian perhatian penting bagi peneliti. Keberadaan dan pendampingan yang dilakukan oleh guru atau pamong sangat berpengaruh dalam perkembangan kehidupan anak-anak selain orang tua. Hal ini didukung oleh hasil penelitian yang dilakukan oleh Chalim dan Anwas mengenai peran penting orang tua dan guru atau pendidik dalam perkembangan karakter anak. Hasil penelitian tersebut menunjukkan bahwa penggunaan internet untuk keperluan pembelajaran cukup tinggi, berhubungan signifikan dengan kepedulian orangtua dalam membimbing anaknya belajar dan mengontrol penggunaan internet, intensitas guru menggunakan internet, tingkat pendidikan orangtua (ibu) serta intensitas siswa membaca buku pelajaran. Menggunakan media sosial, bermain game online, menggunakan internet walaupun intensitasnya tinggi tetapi tidak berhubungan dengan penggunaan internet untuk pembelajaran. Implikasinya bahwa orangtua dan guru dituntut lebih peduli terhadap peserta didik dalam memanfaatkan internet untuk pembelajaran. ${ }^{28}$ Harapan peneliti dengan dilakukannya pengembangan pengelolaan gerakan Sayang Anak Indonesia melalui situs web, dapat menjadi salah satu solusi bagi para pamong dan orang tua untuk memanfaatkan internet sebagai sumber belajar yang positif dan terkontrol.

Berawal dari kedua hal penting tersebut, peneliti melakukan pengembangan pengelolaan gerakan Sayang Anak Indonesia secara nasional melalui website. Mengingat gerakan Sayang Anak Indonesia ini masih baru, maka masih banyak hal yang harus diperbaiki dan dikembangkannya. Pemanfaatan internet sebagai media yang efisien, efektif dan ekonomis menjadi pertimbangan utama. Meskipun internet masih menjadi hal yang baru juga di beberapa daerah, namun pemerintah sudah berusaha agar seluruh wilayah Indonesia bisa dijangkau oleh internet. Luasnya jangkauan wilayah pelayanan GGBI di 29 provinsi di Indonesia, membuat peneliti memilih pemanfaatan internet sebagai media pembelajaran dan sarana komunikasi bagi para pamong yang tersebar di willayah Indonesia.

Hal ini sejalan dengan hasil penelitian Musdaeni, Syahruni dan Lahis yang menyimpulkan bahwa pendidikan karakter dapat mengintegrasikan informasi yang diperolehnya selama dalam pendidikan untuk dijadikan pandangan hidup yang berguna bagi upaya penanggulangan persoalan hidupnya. Pemanfaatan TIK merupakan faktor yang sangat penting dalam mendukung peningkatan kualitas sumber daya manusia. Kemajuan TIK dengan segala potensinya yang ada, jika dikelola dan dimanfaatkan dengan baik akan dapat digunakan untuk mendukung efektifitas pelaksanaan pendidikan karakter yang menjadi perhatian utama kita. Teknologi informasi dan komunikasi harus dimanfaatkan sebagai sarana untuk menerapkan nilai-nilai dasar pendidikan karakter, dan dapat dimanfaatkan sebaik-baiknya agar para generasi bangsa ini mampu meningkatkan kemampuan dan mengembangkan kreativitasnya dalam mengisi pembangunan bangsa Indonesia. ${ }^{29}$ Internet dan Teknologi Informasi Komputer menjadi salah satu media yang bisa digunakan untuk mendukung pendidikan karakter anak dalam upaya untuk meningkatkan sumber daya manusia Indonesia.

\footnotetext{
${ }^{28}$ Saifuddin Chalim and E. Oos M. Anwas, "Peran Orangtua Dan Guru Dalam Membangun Internet Sebagai Sumber Pembelajaran," Jurnal Penyuluhan 14, no. 1 (2018): 42-51.

${ }^{29}$ Syahruni Musdaeni and Nirwana Lahis, "Pendidikan Karakter Melalui Pembelajaran Berbasis ICT," in Seminar Nasional Pendidikan Dan Kewarganegaraan IV. Ponorogo, 2018, 132-39.
} 
Gerakan SAIN muncul dalam rangka usaha untuk menjawab permasalahan keterbatasan gereja-gereja untuk mengakses materi pelajaran Alkitab dengan berbasis kearifan budaya setempat. Selain itu, Gerakan SAIN berusaha untuk menjawab permasalahan implementasi pelajaran Sekolah Minggu dalam kehidupan sehari-hari bagi anak-anak usia 0-15 tahun. Panduan evaluasi yang disusun bersama dari hasil diskusi dalam ToT (training of trainer) III SAIN GGBI, peneliti melakukan evaluasi daring secara acak terhadap perwakilan dari anak, orang tua, pamong dan pendeta melalui google form. Dari hasil evaluasi daring yang masuk terdapat 4 anak, 5 perwakilan orang tua, 4 perwakilan pamong, dan 7 pendeta yang mengisi google form. Evaluasi ini diambil dari empat sisi untuk memperoleh keseimbangan informasi dan sudut pandang terhadap kegiatan gerakan SAIN GGBI.

Anak sebagai pihak yang merupakan fokus utama pelayanan ini menjadi sumber data mengenai keefektivan gerakan ini. Orang tua diharapkan dapat memberi informasi mengenai dampak dari gerakan ini dilihat dari sudut pandang orang tua yang setiap hari selalu bersama dengan anak. Pamong sebagai pelaku utama gerakan ini diharapkan bisa berperan serta dalam memberikan informasi mengenai keberhasilan dan kendala yang dihadapi, sehingga dapat diperoleh bagian-bagian yang perlu diperbaiki dan dikembangkan dalam gerakan ini. Pendeta sebagai supporting system dari pamong diharapkan memberikan keseimbangan informasi mengenai efektifitas dan dampak gerakan ini dilihat dari sudut pandang gereja sebagai lembaga yang bertanggung jawab atas gerakan ini di tingkat lokal.

Hasil-hasil yang diperoleh melalui evaluasi daring antara lain adalah gerakan SAIN GGBI dari sudut pandang anak. Gerakan SAIN merupakan sebuah kegiatan yang mempererat ikatan persaudaraan di antara kelompok dan bisa lebih mengerti pelajaran Alkitab yang disampaikan melalui permainan kelompok. Kelompok anak mengharapkan adaya kegiatan dan pelajaran yang lebih mengasyikkan serta menarik bagi mereka.

Gerakan SAIN dari sudut pandang orang tua sangat bermanfaat karena ada perubahan positif dalam diri anak-anak mereka. Anak-anak menjadi lebih mandiri serta dapat bertanggung jawab terhadap diri sendiri dan lebih peduli terhadap keluarga, teman-teman, serta berkurangnya ketergantungan terhadap gawai. Secara kerohanian, anak memiliki kesadaran pribadi untuk belajar Alkitab di gereja dan mengalami perubahan karakter. Orang tua mengharapkan agar kegiatan gerakan SAIN ini dapat terus berlangsung secara berkesinambungan supaya anak mengalami perubahan positif yang konsisten.

Bagi Gereja yang diwakili oleh pendeta, gerakan SAIN GGBI merupakan gerakan untuk membentuk dan mempersiapkan anak menjadi pemimpin masa depan yang takut akan Tuhan. Perubahan dalam diri anak menjadi pribadi yang mandiri dan bertanggung jawab serta mengikuti Firman Tuhan mulai terlihat dalam proses mengikuti kegiatan SAIN. Gerakan SAIN ini cukup efektif untuk mendidik karakter anak sesuai iman kristiani, namun memiliki beberapa kendala. Kendala yang muncul di lapangan adalah harus selalu mengikuti perkembangan terbaru untuk materi yang inovatif serta kreatif, dan diperlukan konsistensi serta pemahaman sebagai pelengkap Sekolah Minggu bukan kompetitornya. Gerakan SAIN ini juga perlu terus menerus disosialisasikan agar dapat dipahami secara merata oleh gerejagereja Baptis anggota GGBI di seluruh Indonesia. 
Pamong sebagai ujung tombak gerakan SAIN ini menggunakan permainan tradisional untuk mengajarkan nilai-nilai karakter yang sesuai iman kristiani dalam kegiatan kelompok. Pamong menjadi tempat anak untuk mendapatkan motivasi dalam kesulitan yang dihadapi serta bekerjasama dengan orangtua untuk mendampingi anak. Di sisi lain, pamong memerlukan teman atau motivator untuk terus memberikan semangat baik melalui kegiatan pelatihan maupun saluran komunikasi dan informasi yang baik untuk saling berbagi. Dari keempat perwakilan nara sumber evaluasi, gerakan SAIN GGBI ini sudah mulai dirasakan dampaknya. Harapan agar gerakan SAIN GGBI ini terus dilakukan secara berkelanjutan perlu diimbangi dengan ketersediaan media informasi dan komunikasi mengingat fleksibilitas gerakan SAIN ini. Pelaksanaan kegiatan ini mengalami kendala di ide kreatif inovatif yang mengangkat permainan tradisional dalam mengajarkan nilai-nilai karakter kristiani.

Dari uraian hasil evaluasi diatas dapat disimpulkan bahwa: (1) Gerakan SAIN GGBI mendukung gereja dalam membekali dan membentuk karakter anak sesuai dengan nilai-nilai kristiani sebagai pemimpin masa depan; (2) Pamong perlu mendapatkan dukungan baik motiva-i maupun informasi edukatif mengenai kegiatan SAIN yang kreatif dan inovatif. Keterbatasan sumber daya yang dimiliki oleh pamong, menjadi kendala tersendiri dalam melakukan pendidikan karakter anak melalui gerakan SAIN yang berbasis pada fleksibilitas dan konteks budaya; (3) Gerakan SAIN ini cukup penting untuk dilakukan secara berkelanjutan untuk menghasilkan pemimpin masa depan; (4) Fakta menunjukkan bahwa gerakan SAIN ini belum memiliki panduan teknis yang fleksibel dan up to date untuk menolong pamong dalam melakukan kegiatan SAIN di daerah masing-masing

\section{Hasil Pengembangan}

Hasil pengembangan yang dilakukan adalah membuat dan menyusun situs web khusus SAIN GGBI. Website ini diharapkan bisa menjadi sarana informasi dan komunikasi sekaligus panduan bagi para pamong serta orang tua dalam mengadakan kegiatan pemuridan anak-anak. Penyusunan situs web ini dimulai dengan pengumpulan evaluasi sebagai dasar untuk menganalisis kebutuhan. Analisa kebutuhan dilakukan sebagai dasar dalam penyusunan website.

Penyusunan website ini dilaksanakan bertahap dimulai dari menu profil yang terdiri tiga sub bagian sebagai dasar gerakan SAIN, yaitu: (1) selayang pandang SAIN; (2) landasan SAIN; (3) tim nasional SAIN. Tahap kedua adalah menu kegiatan SAIN yang juga terdiri dari tiga sub bagian, yaitu: (1) kegiatan nasional, merupakan kegiatan yang diprakarsai oleh tim nasional; (2) kegiatan regional, merupakan kegiatan yang diselenggarakan oleh masingmasing daerah dalam rangka sosialisasi dan perekrutan pamong; (3) kegiatan lokal, merupakan apresiasi terhadap pamong daerah dalam melaksanakan kegiatan masing-masing dan saling berbagi untuk saling memotivasi. Tahap ketiga adalah dua menu terakhir, yaitu menu forum diskusi dan kontak. Dalam menu forum diskusi terdapat tiga sub bagian, yaitu (1) diskusi; (2) evaluasi; dan (3) bank data. Ketiga bagian ini merupakan bagian utama dimana setiap pamong dapat berdiskusi secara aktif, memberikan evaluasi masing-masing, dan menyampaikan ide-ide kreatif dalam penyusunan perencanaan serta pelaksanaan kegiatan yang dilakukan. Hal ini sangat penting untuk mendapatkan masukan data bagi perkembangan gerakan SAIN dan pengembangan selanjutnya. Menu yang terakhir adalah bagian untuk diskusi secara langsung dengan tim nasional maupun untuk mendaftar sebagai pamong. 
Desain website yang dirancang melalui tahapan uji validasi oleh pakar. Ketiga validator yang menguji adalah: (1) Dr. Yari Dwikurnaningsih, MPd, dari UKSW Salatiga yang menguji dari sisi desain situs web untuk pendidikan; (2) David Vidyatama, SSi dari GGBI yang melakukan validasi dari sisi substansi; dan (3) Dr. Priyantoro Widodo, MTh dari STBI Semarang yang melakukan validasi dari sisi pendidikan agama Kristen. Akumulasi dari uji validasi yang dilakukan oleh ketiga validator apabila digambarkan dalam bentuk tabel adalah seperti yang tergambar di bawah ini:

\begin{tabular}{|l|c|c|}
\hline \multicolumn{1}{|c|}{ Nama } & $\begin{array}{c}\text { Aspek yang } \\
\text { dinilai }\end{array}$ & $\begin{array}{c}\text { Nilai } \\
\text { Rerata }\end{array}$ \\
\hline David Vidyatama, S. Si & Substansi & 4.77 \\
\hline Dr. Yari Dwikurnaningsih, MPd & Desain & 4.11 \\
\hline Dr. Priyantoro Widodo, M.Th & Akademis & 4.8 \\
\hline \multicolumn{2}{|c|}{ Akumulasi Rerata } & $\mathbf{4 . 5 6}$ \\
\hline
\end{tabular}

Tabel 8: Akumulasi penilaian pakar terhadap situs web SAIN GGBI

Berdasarkan akumulasi data di atas, maka situs web yang dirancang mendapatkan nilai rerata akhir 4,56. Ketiga validator memberi kesimpulan akhir mengenai kelayakan situs web yang dirancang dengan mempertimbangkan saran serta masukan. Maka, peneliti melanjutkan proses penelitian ke langkah selanjutnya atau yang terakhir, yaitu revisi sesuai saran dan masukan sehingga dapat menjadi desain situs web yang teruji.

Berdasarkan saran serta masukan yang diberikan oleh para pakar, peneliti melakukan beberapa revisi sesuai dengan catatan yang diberikan. Adapun revisi atau perbaikan yang dilakukan adalah sebagai berikut: Pertama, perbaikan dengan menambahkan menu kesaksian baik dari pamong dan anak, untuk dapat memberi semangat dan motivasi bagi para pegiat anak. Kedua, perbaikan konten bagian landasan dengan tambahan isian tentang pertumbuhan anak dan yang diperlukannya sesuai dengan perkembangan situasional kekinian. Ketiga, perbaikan konten yang memunculkan fungsi manajemen pendidikan. Manajemen pengelolaan pendidikan yang akan ditambahkan ke dalam situs web SAIN GGBI ini akan lebih mengedepankan kepada kontekstualisasi penanaman nilai-nilai karakter kristiani yang bisa dilakukan oleh pamong di daerah

Merujuk kepada identifikasi kebutuhan serta perspektif pengembangan yang diperoleh, maka peneliti menyimpulkan bahwa dengan luasnya jangkauan pelayanan GGBI menjadi satu masalah tersendiri untuk memperkenalkan pola pendidikan karakter anak melalui SAIN GGBI. Dalam hal ini peneliti menilai diperlukan suatu perencanaan dan langkah strategis yang mudah diakses oleh jemaat khususnya pelayan di bawah naungan GGBI. Secara khusus dalam konteks pendidikan karakter anak secara holistic dalam gerakan SAIN GGBI, para pegiat pelayan anak di gereja-gereja lokal dan ataupun pamong anak memerlukan informasi yang sederhana dan mudah dipahami serta bisa dilakukan dalam pelayanan mereka kepada anak-anak. Fleksibilitas kurikulum dalam gerakan SAIN GGBI ini juga menjadi kendala tersendiri bagi pamong untuk mendapatkan ide-ide yang kreatif dan inovatif dalam menyelenggarakan kegiatan SAIN di gereja lokal.

Dari hasil uji validasi, didapatkan bahwa website yang sedang dirancangkan masih memerlukan beberapa perbaikan untuk memenuhi unsur praktis, efektif, efisien, dan ekono- 
misnya. Produk akhir dari desain situs web ini meliputi: 1) selayang pandang SAIN; 2) landasan SAIN; 3) tim nasional SAIN; 4) informasi kegiatan baik secara nasional, regional, maupun local; 5) forum diskusi, evaluasi dan bank data yang menjadi forum komunikasi serta informasi aktif bagi para pegiat anak dalam mengembangkan diri dan kreatifitasnya untuk melakukan kegiatan SAIN di gereja masing-masing; 6) kontak pribadi untuk diskusi personal yang memerlukan perhatian dan penanganan khusus yang tidak untuk konsumsi publik.

Setelah melalui proses revisi, maka situs web mulai diujicobakan penggunaannya kepada lima orang pamong terpilih dari beberapa gereja. Dari hasil evaluasi yang dilakukan secara daring melalui formulir google, evaluasi yang diperoleh adalah seperti yang tampak pada data di bawah ini:

\begin{tabular}{|l|c|c|}
\hline \multicolumn{1}{|c|}{ Responden } & $\begin{array}{c}\text { Total } \\
\text { Nilai }\end{array}$ & $\begin{array}{c}\text { Nilai } \\
\text { Rerata }\end{array}$ \\
\hline Responden 1 & 42 & 4.2 \\
\hline Responden 2 & 50 & 5.0 \\
\hline Responden 3 & 50 & 5.0 \\
\hline Responden 4 & 43 & 4.3 \\
\hline Responden 5 & 42 & 4.2 \\
\hline \multicolumn{2}{|c|}{ Akumulasi Rerata } & $\mathbf{4 . 5 4}$ \\
\hline
\end{tabular}

Tabel 9: Akumulasi evaluasi ujicoba penggunaan website SAIN GGBI

Berdasarkan akumulasi data di atas, maka situs web yang dirancang mendapatkan nilai rerata akhir 4,54. Kelima responden sangat mengapresiasi keberadaan situs web ini dengan beberapa tambahan saran bagi penyempurnaan situs web ini. Peneliti melakukan langkah selanjutnya untuk mulai memperbaiki kembali situs web ini sehingga dapat dipublikasikan secara luas. Revisi akhir situs web yang dikembangkan adalah dengan penambahan sub menu kritik dan saran serta kalender kegiatan. Sementara untuk penambahan video sebagai contoh bahan ajar masih dalam proses pengembangan lebih lanjut.

Dengan didesainnya situs web ini, diharapkan gerakan SAIN GGBI akan menjadi seperti gumpalan bola salju yang semakin membesar dan berdampak bagi keluarga-keluarga baik di dalam gereja maupun di masyarakat. Website ini dirancang sepraktis mungkin dan bila dibandingkan dengan situs-situs pendidikan baik formal maupun informal memiliki kekhususannya tersendiri karena fleksibilitas kurikulum yang digunakan sesuai dengan kebutuhan serta konteks wilayah setempat. Desain web ini juga memuat gambar-gambar kegiatan anak maupun pamong dalam gerakan SAIN untuk menjadi motivasi tersendiri bagi pamong anak di tempat lain untuk terus mengembangkan pendidikan karakter anak melalui kearifan budaya local yang sesuai dengan nilai-nilai kristiani. Pengelolaan kegiatan disesuaikan dengan kebutuhan dan kurikulum gereja masing-masing, meskipun secara nasional mengacu kepada implementasi pelajaran Sekolah Minggu dalam kehidupan sehari-hari. Evaluasi yang dilakukan secara mandiri oleh pamong diolah oleh pengelola nasional untuk menjadi data dan dasar pengembangan kurikulum fleksibel dengan menggandeng bagian Sekolah Minggu GGBI. Desain website ini bisa diakses pamong dengan memasukkan alamat: ggbi.or.id sain di alamat url internet. 
Meskipun website ini sudah mulai bisa dipublikasikan dan diakses oleh para pamong SAIN di daerah masing-maisng, namun peneliti tetap mendorong bagi peneliti berikutnya untuk dapat mengembangkannya dengan system dan penataan fleksibilitas kurikulum yang lebih baik. Maka, pengelolaan gerakan SAIN GGBI akan semakin efektif dan efisien ketika system dan penataannya menjadi lebih baik bagi pelayanan anak-anak Indonesia

\section{Kesimpulan}

Penelitian pengembangan ini menghasilkan kesimpulan sebagai berikut: (1) GGBI sudah memiliki pola pendidikan karakter anak secara holistic dalam bentuk gerakan pemuridan SAIN sejak tahun 2016, namun dalam pelaksanaannya masih memiliki banyak kendala sehingga belum maksimal. Beberapa factor yang menyebabkan munculnya kendala antara lain adalah keterbatasan SDM, luasnya jangkauan wilayah pelayanan GGBI, panduan teknis yang praktis dan efisien untuk menjalankan kegiatan pemuridan SAIN GGBI di tingkat local atau pamong; (2) GGBI telah meluncurkan buku pedoman dasar SAIN GGBI, namun masih diperlukannya sarana panduan teknis yang lebih fleksibel dan mudah diakses dari mana saja. (3) Hasil akhir produk yang dihasilkan adalah adanya media melalui situs web SAIN GGBI yang memuat tentang: Selayang Pandang SAIN, Landasan SAIN, Kegiatan SAIN baik secara nasional, regional maupun local serta Forum Diskusi untuk lebih mengakomodir diskusi antar pamong dalam rangka menemukan pola kegiatan yang lebih sesuai untuk konteks daerah masing-masing.

\section{Ucapan Terima Kasih}

Penulis mengucapkan terima kasih kepada Dr. Bambang Ismanto, M. Si., yang telah banyak membimbing dan memberikan masukan dalam penulisan artikel ini. Apresiasi juga penulis sampaikan kepada Gabungan Gereja Baptis Indonesia yang memberikan kesempatan kepada penulis untuk melakukan penelitian dan pengembangan bagi keberlangsungan pelayanan anak di lingkup Gabungan Gereja Baptis Indonesia. Ucapan terima kasih kepada para validator dan responden dalam kontribusinya demi penyempurnaan hasil pengembangan juga sangat membantu penulis dalam menyelesaikan penelitian pengembangan ini.

\section{Referensi}

Aritonang, Jan S. Berbagai Aliran Di Dalam Dan Di Sekitar Gereja: Edisi Revisi. Jakarta: BPK Gunung Mulia, 2016.

Borg, Walter R., and Meredith Damien Gall. Educational Research: An Introduction Third Edition. New York: Longman, Inc, 1978.

Chalim, Saifuddin, and E. Oos M. Anwas. "Peran Orangtua Dan Guru Dalam Membangun Internet Sebagai Sumber Pembelajaran.” Jurnal Penyuluhan 14, no. 1 (2018): 42-51.

Daniel Nuhamara. "Pengutamaan Dimensi Karakter Dalam Pendidikan Agama Kristen." JURNAL JAFFRAY 16, no. 1 (2018): 93-114. https://doi.org/10.25278/jj71.v16i1.278.

Gabungan Gereja Baptis Indonesia. Minit Kongres X Gabungan Gereja Baptis Indonesia, issued 2015.

Hamka. "Penggunaan Internet Sebagai Media Pembelajaran Pada Mahasiswa IAIN Palu." Hunafa: Jurnal Studai Islamika 12, no. 1 (2015): 95-119.

Helmawati. Pendidikan Keluarga: Teoritis Dan Praktis. Bandung: Remaja Rosdakarya, 2014. 
Hora, Anne Puidk. "Fostering Spiritual Formation of Millennials in Christian Schools." Journal of Research on Christian Education 26, no. 1 (2017): 56-77. https://doi.org/• 10.1080/10656219.2017.1282901.

Ika Budi Maryatun. "Peran Pendidik Paud Dalam Membangun Karakter Anak.” Jurnal Pendidikan Anak 5, no. 1 (2016): 747-52.

Indonesia Patent. Undang-Undang RI Nomor 20 tentang Sistem Pendidikan Nasional, issued 2003.

Jabar Ekspress. "Pendidikan-Karakter-Hadapi-Era-Industri-4-0.” Jabar Ekspress.Com, 2018.

Kamus Besar Bahasa Indonesia. 5th ed. Badan Pengembangan Bahasa dan Perbukuan, Kementerian Pendidikan dan Kebudayaan Republik Indonesia, 2019.

Marcelino Sumolang. "Peranan Internet Terhadap Generasi Muda Di Desa Tounelet Kecamatan Langowan Barat.” Journal II, no. 4 (2013).

Muryawati, Monica, Candra Agung Pambudi, Royo Haryono, Noto Sumarto, Juliati Dharmawan, Siska Rafika, Doni Wijaya, et al. Layang-Layang \& Rujak: Melayang Tinggi Dalam Beragam Rasa Dan Warna Bagi Anak Indonesia-Bunga Rampai Buku Panduan SAIN GGBI. Edited by Monica Muryawati. Jakarta: Gabungan Gereja Baptis Indonesia, 2018.

Musdaeni, Syahruni, and Nirwana Lahis. "Pendidikan Karakter Melalui Pembelajaran Berbasis ICT." In Seminar Nasional Pendidikan Dan Kewarganegaraan IV. Ponorogo, 132-39, 2018.

Rahayu, Endang Sadbudhy. "Implementasi-Pendidikan-Karakter-Era-Revolusi-Industri-40Ala-Smk-Negeri-3-Bandung." Psmk.Kemdikbud.Go.Id, 2019.

http://psmk.kemdikbud.go.id/konten/4297/implementasi-karakter-era-revolusi-industri40-ala-smk-negeri-3-bandung.

Raihan Putry. "Nilai Pendidikan Karakter Anak Di Sekolah Perspektif Kemendiknas." Gender Equality: Internasional Journal of Child and Gender Studies 4, no. 1 (2018): $39-54$.

Satria MA Koni. “'Pengaruh Jejaring Sosial Terhadap Pendidikan Karakter Peserta Didik” (Studi Kasus Di SMKN 1 Bone Raya Kab. Bone Bolango Provinsi Gorontalo).” TADBIR : Jurnal Manajemen Pendidikan Islam 4, no. 2 (2016): 37-43.

Sugiyono. Metode Penelitian Dan Pengembangan: Research and Development. Bandung: Alfabeta, 2015.

Suryana, Yaya, and H.A. Rusdiana. Pendidikan Multikultural: Suatu Upaya Penguatan Jati Diri Bangsa - Konsep-Prinsip-Implementasi. Bandung: Pustaka Setia, 2015.

Suwarti, Bambang Sumardjoko, and Sabar Narimo. "Pemanfaatan Internet Sebagai Media Pembelajaran Di SD Negeri 1 Sindurejo Kecamatan Toroh Kabupaten Grobogan.” Universitas Muhammadiyah Surakarta, 2016. 